\title{
Blended Coaching and Coaching Curve Approaches in Enhancing Teaching Competency: A Case Study
}

\author{
Noel Jimbai Anak Balang, Zamri Mahamod, Nor Aishah Buang \\ Faculty of Education, National University of Malaysia, Bangi, Malaysia \\ Email: noeljimbaibalang@gmail.com
}

How to cite this paper: Balang, N. J. A., Mahamod, Z., \& Buang, N. A. (2019). Blended Coaching and Coaching Curve Approaches in Enhancing Teaching Competency: A Case Study. Creative Education, 10, 2718-2729. https://doi.org/10.4236/ce.2019.1012198

Received: October 18, 2019

Accepted: November 25, 2019

Published: November 28, 2019

Copyright $\odot 2019$ by author(s) and Scientific Research Publishing Inc. This work is licensed under the Creative Commons Attribution International License (CC BY 4.0).

http://creativecommons.org/licenses/by/4.0/

\section{cc (i) Open Access}

\begin{abstract}
The purpose of this study is to highlight the approach of integrated coaching in enhancing teacher capacity development by School Improvement Specialist Coach Plus (SISC+). The coaching approach is a combination of facilitative, directive and dialogue coaching. The coaching curve by Bradley William was also employed in this study. This case study involved an in-depth study of a teacher teaching history subject from 2018 to mid 2019. Data were collected using the Teacher Coaching Tool (TCT) instrument used by SISC+ as a standard document to guide teachers. The findings showed that the teacher's teaching and learning (TnL) competency in the classroom was improved in writing learning objectives, activity-based, pedagogical content knowledge and conclusions aspects of TnL. It is recommended further study on the effectiveness of SISC+ coaching practice with a larger sample to address the various issues in the field of coaching.
\end{abstract}

\section{Keywords}

Guided Teachers (GT), School Improvement Specialist Coaches Plus (SISC+), Teaching and Learning (TnL) Teachers Coaching Tool (TCT)

\section{Introduction}

Knowledge and coaching skills among School Improvement Specialist Coach Plus (SISC+) are the new millennium educational transformation in Malaysia (Ministry of Education Malaysia, 2013). In transforming teaching and learning (TnL) among teachers, SISC+ was demanded to diversify their teaching approach when teaching (Mohd \& Jamil, 2017, Said, Jamian, \& Sabil, 2016; Asnah Hamid, 2014). In this context, SISC+ needs to master a variety of effective 
coaching approaches to attract teachers to add new knowledge in line with the role of SISC+ as an instructional coach. Teachers should also have a high degree of professionalism by always ensuring that they are equipped with the latest pedagogical knowledge (Sarabiah \& Zamri, 2016, Siti Fatimah \& Ab. Halim, 2010). Among the challenges faced by SISC+ is to determine the coaching approach that is considered to be the catalyst for teacher quality (Knight, 2019, Joyce \& Shower, 2010; Neagley, 2015).

The field of instructional coaching is considered the catalyst for quality TnL processes (Sarabiah \& Zamri, 2016; Noel \& Zamri, 2017). The SISC+ post introduced in 2012 has greatly helped teachers increase their competency in TnL in the classroom (Rahman \& Mahamod, 2016, Bibi et al., 2019). In this context, SISC+ plays a role in helping teachers in the development of professionalism to improve the quality of their learning (Knight, 2019, Elena, 2016). In addition, effective learning in the context of coaching involves two stakeholders; namely, the teacher who guides (supervisor/mentors/coaches) while those who receive guidance (mentee/coachee/protégé) (Norhasni, 2006, Knight, Joyce, \& Shower, 2013). Teachers are encouraged to master the pedagogical skills of a successful TnL process. The Planning and Policy Research Division (2012) has outlined that teachers need to equip themselves with appropriate knowledge, attitudes, behaviors and skills (Mohd \& Mohd, 2017). In addition, SISC+s need to ensure effective coaching approaches that are offered to meet the needs of the 21st century education. In response to this, the researchers of this study introduced blended coaching and a coaching curve to enhance teachers' teaching competency.

\section{Problem Statement}

Much has been said about the need for impactful teaching approaches especially in the pursuit of improving teacher teaching in the classroom (Rozita Radhiah et al., Sarabiah Jusoh \& Zamri Mahamod, 2016). Lack of coaching skills can lead to SISC+ being negatively perceived by teachers, Mohd Hilmi \& Jamil (2017), Sarabiah \& Zamri, 2016 argue that teacher-led behavior can change through effective coaching approaches and that teachers can change their behavior to provide better teaching if systematically guided. According to Sarabiah and Zamri (2017) the practice of coaching is to improve teachers TnL process. Jim Knight (2013) and Nieto (2014) point out that coaching practice is an effort to motivate, coordinate and guide teachers in TnL so that they are able to perform all teaching related functions effectively (Zubaidah, Hamidah, \& Wahiza, 2019; Radzuwan Ab Rashid, Safawati, \& Kamariah, 2016; Rozita Radhiah, Mohd, \& Azhar, 2016). Recognizing the importance of coaching practices in determining effective implementation of curriculum management, most schools have made SISC+ coaching practice a necessity. The question is whether the coaching approach implemented by SISC+ is acceptable to the teachers or are they using effective coaching approaches and practices? Given the coaching practices conducted by 
SISC+ in due course, it also raises the question of whether such training will have an impact on teacher professionalism and student achievements. Therefore, this study aimed to determine the effectiveness of the blended coaching and the coaching curve approaches in improving teacher competency in teaching and learning.

\section{Research Objective}

This study aimed to identify the effectiveness of the blended coaching and coaching curves approaches in developing teachers competency in TnL.

\section{Research Question}

One research question developed in this study which is "Can a blended coaching and the use of coaching curve approach can improve teachers competence in TnL?

\section{Literature Review}

Coaching is a part of the professional development aspect of teachers. The Coaching Curve by Bradley William (2017) was used in this study which was found to be appropriate for SISC+ coaching practice. In a study conducted by Zakaria, Sarkauvi, Ibnis and Lee (2013) in Sarabiah \& Zamri, 2016 found that teachers were able to receive the guidance and mentoring pattern at a moderate level of 3.05 mean score. Chuan et al. (2014) found their perception of SISC+ by stakeholders who are teachers, school administrators and district education officials indicate that their perceptions are high when interacting. In addition, the perception of SISC+ in relation to the expectations of school administrators and District Education Officers (PPDs) is also high. According to Neufold and Roper; (Poglino et al., 2014) effective instructional guidance is to encourage collaborative practice and reflection on the teaching and learning process. In this context, a mentor's teacher needs regular and consistent mentoring. Teachers cannot move by themselves. They need specialists who can help increase classroom capacity. According to Knight \& Jake (2007) there are three aspects that determine the effectiveness of mentoring and mentoring: technical guidance, collaborative problem solving and peer support A study conducted by Neufold and Roper (2013) found that the role of instructional coaches in the coaching process is very important to the quality of teacher teaching. This study is relevant to highlight because of changes in curriculum that have to be made in line with the demands of 21st century learning. Zakaria (2010) and Syed Ismail Syed Mustapa (2010), conducted a study to identify the effectiveness of mentor guidance on teacher training teachers found that teacher mentoring on teacher training is significant and very strong in preparation for teaching. Researching this finding could summarize the role of teacher guidance and SISC+ certainly affects the quality of PdPc teachers in the classroom. Tshabalala (2013) found 
that teachers' perceptions were positive about coaching programs. This qualitative study calls for programs like peer coaching to be designed that will surely produce quality teaching. Bhavani \& Zamri (2016) conducted a study on the perceptions of trainee teachers on supervision and guidance provided by the supervisor for teaching training programs showed that perceptions of trainee teachers on the role of the mentor teacher at a moderate level of 3.0 mean score. Based on recent research, it was clearly stated that the role of the mentor teacher is very important in the development of a teacher's career. Guided teachers will have the confidence to teach if they continue to provide support and encouragement by the school and the SISC+.

Blended Coaching Approach is introduced and used by researchers in this research. Blend Coaching is a combination of three coaching approaches introduced by Jim Knight (2017), which is facilitative, directive and dialogical coaching. Additionally, researchers have also adapted the Coaching Curve introduced by Bradley William (2017).

\subsection{Facilitative Coaching}

According to Jim Knight (2017) facilitative coaching looks at the right of equality between coach and coachee. Sir John Whitmore (2002) argues that the relationship between coach and coachee is based on a cohesive relationship in building confidence and trust and reducing stress for the coachee.

\subsection{Directive Coaching}

Directive Coaching refers to the role of the coach in giving directions to the coachee. In this context, the coach sets goals that the coachee needs to accomplish based on the ability of the coachee with the guidance of the coach. The coaching approach is more about the professional relationship between the coach and coachee. According to Jim Knight (2017), coaching in this way only builds relationships that are respected but not together in decision making.

\subsection{Dialogical Coaching}

Dialogical Coaching refers to coaches who consider the coachee a good friend. Relationships are built on mutual trust in deciding what to achieve. Dialogue coaching also sets the coachee that needs to make a decision. Coaches and coachees share expertise, knowledge and information for mutual benefit. According to Jim Knight (2017), dialogue coaching promotes a balance between coach and coachee opinion.

\section{The Coaching Curve by Bradley William (2017)}

\section{1) Structured Demonstration}

Structured demonstration is also the most comfortable coaching method for teachers because it absolves them from any responsibility of the overall outcomes. In actuality, this method of coaching does play a vital role in the coach- 
ing process, but not in the way most coaches and teachers anticipate. When trying to accelerate a teacher's change in condition, structured demonstration lesson provide two important outcomes that together form the foundation of the entire coaching partnership. First, a structured demonstration lesson provides an opportunity of either challenge or enforce a current set of beliefs and principles held by the teacher about what their students are capable of doing and what knowingly or not, guides decisions throughout the lesson. Second, a structured demonstration builds the coach's credibility and repute which in turn fosters a stronger working relationship between the coach and the teacher. Beyond these initial outcomes however, additional demonstrations will not further the teacher's change in condition, and can even begin to degrade the repute of the coach as teachers begin to "self-certify" due to repeated observations.

\section{2) Data driven Observation}

During these data-driven observations, observable behaviors should be recorded through quantitative observations that are both objective and measureable. These pieces of data are then used to set goals for the coaching cycle and to determine which coaching methods should be used to mediate the greatest change in a teacher's current condition. In short, lesson observations provide the data needed to effectively select a set of coaching objectives or to determine if a completed coaching cycle was effective, not a coaching methodology in and of itself.

\section{3) Real-Time Corrective Feedback}

In real time corrective feedback, the coach moves themselves from their usual position, out of the way of the lesson, to a position that allows them to inject themselves into and retreat themselves from the lesson with minimal impact to the flow of the activity. In this method, coaches put down their notes and actively observe the lesson for opportunities to refine and calibrate a teacher's instructional practise. As instances such as these occur, the coach steps in and provides brief, succinct, and do-able prompts that the teacher implements immediately. The coach then retreats themselves from the lesson until the next opportunity for either refinement or enhancement arises. This method allows a coach and a teacher to work together in real-time to enhance instruction in a way that eliminates hindsight and explicitly connects a teacher behavior to an antecedent occurrence that can be replicated in future lessons.

\section{4) Resuscitation}

One of the most important jobs of a coach during any supported lesson is to ensure that the lesson is successful. This is true whether in real-time corrective feedback or any other coaching methodology excluding a lesson observation. If the lesson strays too far from its objective, the teacher loses instructional control, or requires an intervention that necessitates more than a simple directive, it is the coach's obligation to step in as briefly as possible to get the lesson back on track or model a given intervention for the teacher to replicate. This coaching methodology is call resuscitation. When a coach resuscitates a lesson they are 
not taking total control of the teacher's classroom for the reminder of the activity, they are only stepping in to provide a piece of the lesson that they observed that the teacher cannot provides themselves. This method requires coaches to have a predetermined "exit strategy" or a way to transition the teacher back into the lesson without disturbing the now resurrected flow the activity.

\section{5) Pass the Pen}

In pass the pen, the coach positions themselves in the same way that they would for real-time corrective feedback or resuscitation, but for this coaching methodology the coach is available to be called upon by the teacher to step in to demonstrate an aspect of the lesson that they are feeling uncomfortable with or that they wish to improve. The flow of the lesson is not disturbed because the teacher needs only to pass off the control of the lesson by trading positions with the coach or "passing the pen". The coach then takes over the lesson as long as deems necessary to provide a demonstration of the lesson aspect or procedure. Pass the pen also shows teachers how to anticipate situations that they are unsure of how to handle which will help them replicate future conditional improvements as they learn to predict outcomes and not merely live in the moment of the lesson.

\section{6) Narrated Lessons}

Narrated lessons provide coaches with opportunity to both demonstrate an effective lesson while simultaneously pointing out important aspects of the lesson in real time. This coaching method places the coach and the observing teacher out of the way of the lesson so that the coach can whisper to the observing teacher during instruction. Another major benefit of this style of coaching is that it shows teachers two important things. First, the method being taught can and does work for their students and second, that the method is something that their peers are able to do as well, thus removing the stigma that only the coach can make the method work.

\section{7) Co-Plan/Co-Teach}

The most effective coaching methodology that coaches and teachers can use to improve a teacher condition is Co-Plan/Co-Teach. It is also the least frequently used coaching methodology as it requires the greatest time commitment, and it equally shares the responsibility for lesson planning, preparation, and delivery between the teacher and coach. In this coaching method, the coach and the teacher meet before the lesson to plan the procedures, assign roles for who will teach which portion of the lesson and set a desired and measurable coaching objective for the teacher that can be objectively measured. The team then teaches the lesson together according to their agreed upon plan and meets to discuss the attainment of the predetermined coaching objectives after the lesson. This method sets teachers up for the greatest success by making sure that quality preparation has occurred before the lesson, demonstration and corrective feedback is given during the lesson, and effective reflection on objectively measurable growth is discussed after the lesson. 


\section{Coaching curve}

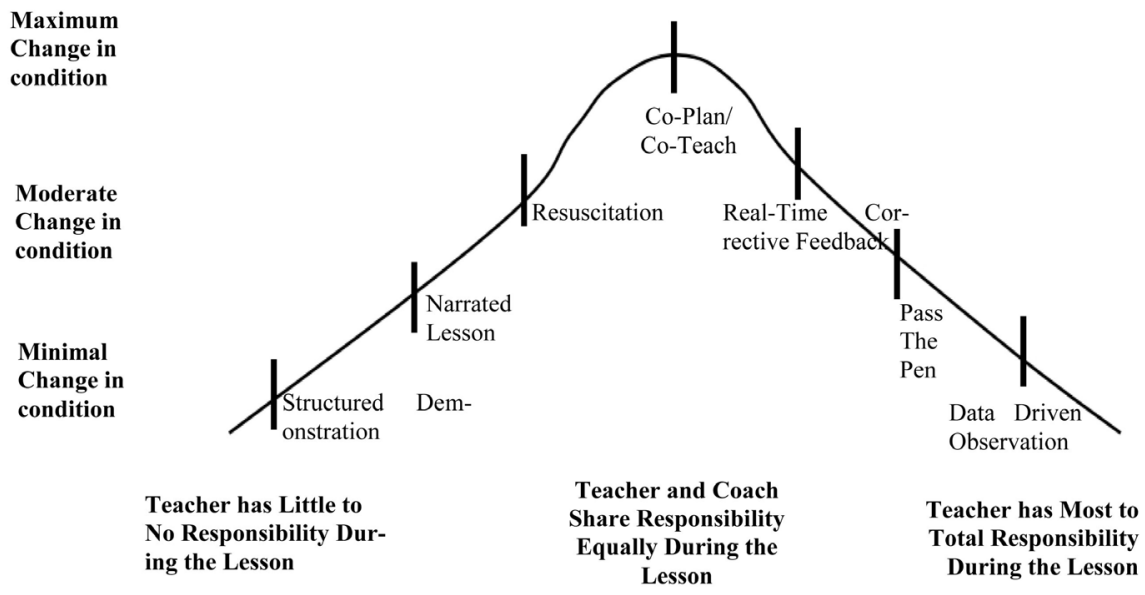

\section{Research Methodology}

This study is a case study involving a research subject using a blended coaching approach and coaching curve in developing teacher competency. According to Merriam (2018), Cohen, Manion \& Marrison (2007) case studies help researchers uncover and study a problem, a phenomenon or a novelty with the purpose of identifying and analyzing a given problem, beliefs, opinions and generalizations (Merriam 2018, Miller, Creswell, 2005) This study involved only one secondary school teacher which is teaching history subject in the district of Selangau, Sarawak. The purpose of selecting the subject was too close to the targeted sample. Selection of a subject is appropriate because a test subject is inexperience in teaching. A subject also had three years of teaching experience. The researcher found that the subject was appropriate because have been coached for over a year. Data was collected using the Teachers Coaching Tool (TCT) used by SISC+ during classroom observations. This observation form is a mandatory document provided by the Ministry of Education Malaysia and complies to the Malaysian Education Quality Standards (SKPMg2).

\section{Findings}

Based on the Matrix Achievement instrument, it was found that the teacher of the study has shown improvement in $\mathrm{TnL}$ as observed through the four observation cycles conducted in one year; from January 2018 until January 2019. In the first observation, the teacher scored $17 \%$ followed by $24 \%$ in the second observation, $34 \%$ in the third and $38 \%$ which is the highest score in the fourth cycle (Table 1).

\section{Discussion and Recommendations}

Overall, the study subjects showed improvement in the four cycles observation. This proved that the study subjects recognized the need to enhance their teaching skills and quality to the optimum level. The impact of the blended coaching 
Table 1. Teachers matrix score using the instrument achievement in four cycle observation.

\begin{tabular}{ccccc}
\hline Aspects & \multicolumn{3}{c}{ Score } & \\
\hline Learning Objective & 2 & 2 & 1 & 3 \\
Lesson Planning & 1 & 2 & 3 & 3 \\
Students Based Activity & 2 & 2 & 3 & 4 \\
Communication Skill & 2 & 3 & 3 & 4 \\
Student Focus and Attention & 1 & 2 & 3 & 3 \\
Learning Resource Materials & 1 & 2 & 3 & 4 \\
Content Knowlegde & 2 & 3 & 3 & 3 \\
Verbal Assessment & 2 & 2 & 3 & 3 \\
Formative Assessment & 1 & 2 & 3 & 4 \\
Conclusion & 1 & 2 & 3 & 3 \\
Learning Reflection & 2 & 2 & 3 & 4 \\
Total Score $=\mathbf{4 0 \%}$ & $\mathbf{1 7 \%}$ & $\mathbf{2 4}$ & $\mathbf{3 4 \%}$ & $\mathbf{3 8 \%}$ \\
\hline
\end{tabular}

the used of coaching curve approaches is expected to improve the quality of TnL. The best practice of coaching is the catalyst for student achievements (Sarabiah \& Zamri, 2016, Noel Jimbai \& Zamri, 2017). This finding is in line with some previous studies such as Ismail Mohamed (2014), Mohd Fuad Omar (2014) and Normazira (2013). In the study of the role of teacher guidance in novice teachers, this study found that teachers need guidance from the experienced teachers, and the study also shows that novice teachers are still at the forefront of assessment, pedagogy and curriculum skills. Novice and inexperienced teachers are in dire need of SISC+ guidance. Syed Ismail (2013) conducted a study to identify the teaching practice of lecturers and mentor teachers in $\mathrm{TnL}$ with respondents consisting of 535 trainee teachers, 144 lecturers and 159 teacher teachers. This study was quantitative and qualitative. The findings of this study show that the teaching practice of teaching for lecturers and teachers is the dominant aspect of teaching implementation with the mean of 4.59. Indirectly, this study shows that trainee teachers are in dire need of ongoing help and guidance towards furthering their TnL process. This study is in line with studies conducted by Sarabiah \& Zamri, 2016, Noel Jimbai \& Zamri (2017), Mohd Hilmi \& Jamil Ahmad (2017) who found that SISC+ perceptions and practices in Bangsar and Pudu district were well received by teachers.

From the findings of this study it can be concluded that teachers are still in need of continuous training approaches to further enhance the quality of teaching in the classroom. In this context, the role of SISC+ is considered to transform the teaching pattern of teachers towards a greater emphasis on skills and knowledge-seeking processes (Wan Norhasma \& Nurahimah Mohd Yusoff, 2019; Ansawi \& Pang, 2017; Suzalin, Ilda Salwani, \& Noorazam, 2014; Wong \& Ching, 2015). Efforts on behalf of teachers need to be continued to enhance the 
skills of teachers to implement effective TnL in the classroom. These efforts not only help teachers improve the quality of teaching indirectly, it also helps students achieve the learning objectives and skills required (Malaysian Education Development Plan (PPPM), (Wan Norhasma \& Nurahimah Mohd Yusoff, 2019; Minder Kaur, 2017; Radzuwan Ab Rashid et al., 2016; Aniza \& Zamri 2015; Shamsudin \& Kamarul, 2011). This study provides the impression that SISC+ needs to have a coaching approach as well as skills and knowledge in terms of assessment, pedagogy and curriculum (Management Handbook 3.0). Guided teachers certainly expect SISC+ to help raise their professionalism to the optimum. Therefore, in order to achieve the quality of effective coaching guidance efforts to improve the practice of coaching within SISC+ need to be strengthened from time to time in line with the needs of the 21 st century education. A comprehensive and integrated effort should be taken by all stakeholders. The research conducted contributes significantly to the SISC+ nationwide reflecting on the quality of coaching (Ahmad et al., 2016, Bibi et al., 2019). Based on some previous studies it was found that teachers can accept coaching by SISC+ but this does not mean that policy makers need to be satisfied (Noel Jimbai et al., 2019). They should use these and other studies as benchmarks to evaluate the effectiveness of the programs implemented. Policymakers not only provide courses, but also practice quality coaching practices in conjunction with the delivery of information to further enhance their coaching skills. Policy makers such as the Ministry of Education Malaysia should continue to strengthen the practice of coaching more effectively.

In addition, school leaders are also responsible for ensuring that teachers at the school provide cooperation and openness to SISC+ who comes to the school to implement the TnL process in the classroom. School administrators should use the expertise of SISC+ has to offer and enhance the professionalism of teachers in schools. Through the cooperation and practice of the Professional Learning Community (PLC) that exists between administrators and SISC+ it is expected to have a positive impact on TnL. Coaching practices by SISC + can provide a holistic view of the effectiveness of SISC+ as an agents of change in TnL in schools. In this context, SISC+ is strongly encouraged to continue providing quality coaching to teachers. The impact of ongoing guidance and integrity can certainly enhance the professionalism of the teachers being guided. In addition, the impact of the guidance provided can also serve as a benchmark for the school to implement various forms of internal training that lead to teacher development in the school.

The practice of SISC+ coaching is an important step towards enhancing teacher professionalism (Ahmad \& Zamri, 2015; Jack Canfield \& Chee, 2013). Therefore, it is recommended that further studies involving the impact of SISC+ skills and guidance be given to a larger sample size and involving more teachers either at the national school or national level to make the overall picture of teacher acceptance more clear. 


\section{Conclusion}

By sharing the responsibility and choosing clear coaching methodology that meets the needs of each individual teacher, coaches can make much greater and longer lasting change in a teacher's condition (Borman \& Feger, 2006, Shaun \& Harbour, 2009). Teachers bring their best skills and abilities to every lesson that they teach, by mediating lessons in real-time, coaches have the unique ability to help teachers grow their skills and not merely reflect upon them after the conclusion of an activity (Rusni, 2013). Blended coaching and coaching curve offer an approach to both see and understand the connection between teacher growth and the shared responsibility of coaching to improve an individual teacher's current condition. The specific coaching methods, their order of implementation and their overall effect are dependent upon the use of objectively observable data and the relationship that formed between the coach and the teacher.

\section{Acknowledgements}

This research was partially supported by grant received from the Faculty of Education, Universiti Kebangsaan Malaysia-PP-FPEND-2019.

\section{Conflicts of Interest}

The authors declare no conflicts of interest regarding the publication of this paper.

\section{References}

Ahmad, A., \& Mahamod, Z. (2015). Tahap Kemahiran Guru Bahasa Melayu Sekolah Menengah Dalam Melaksanakan Pentaksiran Berasaskan Sekolah Berdasarkan Jantina, Opsyen dan Tempat Mengajar. Jurnal Pendidikan Bahasa Melayu, 1, 40-46.

Ahmad, S. M., Radzuwan, A. R., Kamariah, Y., \& Safawati, B. Z. (2016). Exploring the School Improvement Specialist Coaches' Experience in Caoching English Language Teachers. International Arab World English Journal, 7, 243-255. https://doi.org/10.24093/awej/vol7no3.19

Ansawi, B., \& Pang, V. (2017). The Relationship between Professional Learning Community and Lesson Study: A Case Study in Low Performing Schools in Sabah, Malaysia. Sains Humanika, 9, 63-70. https://doi.org/10.11113/sh.v9n1-3.1144 http://www.sainshumanika.utm.my/index.php/sainshumanika/article/view/1144

Bibi, Z., Yamat, H., \& Wahi, W. (2019). School Improvement Specialist Coaches plus (SISC+) Teacher Coaching in Malaysia: Examining the Studies. International Journal of Contemporary Applied Researches, 6, 125-136. https://www.researchgate.net/publication/334724514 SCHOOL IMPROVEMENT SP ECIALIST COACHES PLUS SISC TEACHER COACHING IN MALAYSIA EXA MINING THE STUDIES

Borman, J., \& Feger, S. (2006). Instructional Coaching: Key Themes from Literature. https://www.brown.edu/academics/education-alliance/sites/brown.edu.academics.educ ation-alliance/files/publications/TL Coaching_Lit Review.pdf

Canfield, J., \& Chee (2013). Coaching and Mentoring: A Handbook for Coaches. New York: Columbia University Press. 
Creswell, J. W. (2005). Research Design: Qualitative, Quantitative and Mixed Methods Approaches (Edisi ke-2). Thousand Oaks, CA: Sage.

Hamid, A. A. (2014). Penyeliaan Dalam Pengurusan Organisasi Pendidikan: Satu Pendekatan Kaunseling. Jurnal Pendidikan. Institut Aminuddin Baki, Kementerian Pendidikan Malaysia, Jilid 4, Bil. 2.

Jimbai, N., \& Zamri, M. (2017). Penerimaan Guru-Guru Bahasa Melayu Terhadap Bimbingan dan Pementoran SISC+. In Dalam Seminar Penyelidikan Pendidikan 2017. Fakulti Pendidikan, Universiti Kebangsaan Malaysia (Tema: Penyelidikan Berkualiti Teras Kecemerlangan Pendidikan) (pp. 280-291). Bangi: Fakulti Pendidikan, Universiti Kebangsaan Malaysia.

Joyce \& Shower (2010). Instruction Supervision: A Behaviour System. Boston, MA: Allyn and Bacon.

Jusoh, S., \& Mahamod, Z. (2016). Tanggapan, Amalan dan Keberkesanan Bimbingan Pegawai SISC+ dari Perspektif Guru Bahasa Melayu. In Prosiding Seminar Pascasiswazah Pendidikan Kesusasteraan Melayu Kali Kelima (pp. 42-52). Fakulti Pendidikan, Universiti Kebangsaan Malaysia.

Knight, J. (2019). Instructional Coaching for Implementing Visible Learning: A Model for Translating Research into Practice. Thousand Oaks, CA: Corwin. https://doi.org/10.3390/educsci9020101

Knight, J., \& Jake, C. (2007). Paper: Studying the Impact of Instructional Coaching. https://www.instructionalcoaching.com/downloads/pdfs/NationalCoachingConference Melbourne.pdf

Ministry of Education Malaysia (2013). Bidang Keberhasilan Utama Negara (NKRA). https://www.moe.gov.my/menumedia/media-cetak/penerbitan/1818-pelan-pembangu nan-pendidikan-2013-2025/file

Mohamad, S., \& Jasmi, K. A. (2011). Penyeliaan Dalam Pengajaran dan Pembelajaran. Universiti Teknologi Malaysia.

Mohd Hilmi, A., \& Jamil, A. (2017). Persepsi Guru Terhadap Program Pembimbing Pakar Peningkatan Sekolah (SISC+). In Seminar on Transdisciplinary Education (pp. 198-205).

https://sted18.wordpress.com/prosiding-sted-2017/proceeding/

Mustapa, S. I. S. (2010). Amalan bimbingan pengajaran pensyarah dan guru pembimbing dalam program mentoring praktikum serta impaknya terhadap kualiti guru pelatih. https://www.ukm.my/jurfpend/jurnal38/7SYEDISMAILSYEDMUSTAPA.pdf

Neagley, T. (2015). Hand Book for Effective Supervision of Instruction (3rd ed., pp. 2-3). Upper Saddle River, NJ: Prentice-Hall, Inc.

Nieto, R. J., \& Rirth (2014). Clinical Supervision. Boston, MA: Houghton Mifflin.

Norhasma, W., \& Yusoff, N. M. (2019). SKPMg2 (Standard 4) as Tools to Upgrade Teachers Teaching Quality. Journal of Educational Research and Indigenous Studies, 1, 1-9. http://www.jerisjournal.com

Rahman, S., \& Mahamod, Z. (2016). Kreativiti Dalam Pengajaran dan Pembelajaran. Universiti Kebangsaan Malaysia.

Said, R. R., Jamian, A. R., \& Sabil, A. M. (2016). Pengetahuan dan Kefahaman Skop Pengajaran dan Pembelajaran Bahasa Melayu dalam Kalangan Jurulatih Pakar Pembangunan Sekolah (SISC+). International Journal of Education and Training, 2, 1-9. http://www.injet.upm.edu.my

Shaun, A., \& Harbour, M. (2009). The Coaching Toolkit. London: Sage Publication. 
Somasundram, B., \& Mahamod, Z. (2016). Prosiding Seminar Pascasiswazah Pendidikan Kesusasteraan Melayu Kali Kelima. Fakulti Pendidikan, Universiti Kebangsaan Malaysia.

Tshabalala, T. (2013). Teachers Perception towards Classroom Instructional Supervision: A Case Study of Nkayi District in Zimbabwe. http://ijsse.com/sites/default/files/issues/2013/v4i1/paper/Paper-3.pdf

William, B. (2017). High Impact Instruction. Upper Saddle River, NJ: Prentice Hall.

Zain, R. M. (2013). Pengurusan Penyeliaan dalam Suasana Sekolah: Isu dan Strategi. Jurnal Kementerian Pendidikan, 2, 30-43.

Zakaria, N. A. B. (2010). Keberkesanan bimbingan guru pembimbing terhadap latihan mengajar guru pelatih UPSI. In Proceeding of the 4th International Conference on Teacher Education: Join Conference UPI \& UPSI (pp. 49-58).

http://file.upi.edu/Direktori/PROCEEDING/UPI-UPSI/2010/Book_1/KEBERKESANA N BIMBINGAN GURU PEMBIMBING TERHADAP LATIHAN MENGAJAR GU RU PELATIH UPSI.pdf 